\title{
DATE PALM WASTE IN STARTER-GROWER DIETS AND IMPACT ON PRODUCTIVE AND PHYSIOLOGICAL PERFORMANCE OF BROILERS
}

\author{
A.I. El-Faham ${ }^{1}$; Nematallah G.M. Ali ${ }^{1}$; Reham A.M. Ali $^{2}$ and M.A.M. Abdelaziz ${ }^{1 *}$ \\ ${ }^{1}$ Poultry Production Department, Facultyy of Agriculture, Ain Shams University, Cairo, Egypt. \\ ${ }^{2}$ Anim. and Poult. Prod. Dept. Fac. of Agric. and Nat. Resources, Aswan Univ., Egypt. \\ *Corresponding author: E-mail: mrwanabdelaziz@agr.asu.edu.eg
}

(Received 29/5/2017, Accepted 11/7/2017)

\section{SUMMARY}

$\mathrm{T}$ The current study was designed to evaluate growth performance, carcass characteristics and some blood plasma parameters on unsexed Hubbard broiler chicks fed different levels of protein and Mid-rib of date palm (MDP) up to five weeks of age. Four dietary treatments, using 160 chicks, each group comprised of 40 chicks in 5 replicates of 8 chicks each. Two levels of crude protein (required level; control) and (low [-2\% crude protein]; T1) and two levels of MDP (5\%; T2 and 10\%; T3) were used to replace yellow corn grains found in control diet. At the end of experimental period at 5 weeks of age, 3 birds from each treatment were randomly selected and slaughtered for carcass, tibia and some plasma parameters. Obtained results indicated that chicks fed required protein diet (control) showed the highest live body weight and best feed conversion ratio compared with those fed low protein diet (T1). Moreover, chicks fed MDP (T2 or T3) diets reflected the lowest live body weight and worse feed conversion ratio compared with other dietary treatments. In regard to carcass characteristics parameters; carcass weight, total edible parts and abdominal fat $\%$ and carcass parts $\%$ (wing and drumstick \%), recorded insignificant figures were observed when chicks fed different dietary treatments. However, liver, giblets, thigh and breast percentages recorded significant differences within dietary treatments. Additionally, tibia bone measurements (wet tibia weight, tibia length, tibia width and tibia Seeder index) showed insignificant differences within dietary treatments. Also blood plasma parameters [total protein, albumin, globulin, uric acid, total lipids, triglycerides, cholesterol and alanine transaminase (ALT)] were not altered, while; plasma aspartate transaminase (AST) concentration was increased by feeding low protein diets (T1). In conclusion, feeding broiler chickens on balanced diets is more successful in regard to growth performance, feed conversion ratio and carcass characteristics.

Key words: date palm, broilers, performance, blood plasma, tibia traits.

\section{INTRODUCTION}

Feedstuffs for economical poultry production are considerably limited in many regions of the world, such problem has become even worse by the tendency of using grains in the production of biofuels and the subsequent increase in the prices of feedstuffs. This is becoming even worse due to the use of different crops such as maize in biofuel production and the subsequent increase in the price of energy sources in poultry and animal rations (Farrell, 2005; Lumpkins and Batal, 2005; Swiątkiewicz and Koreleski, 2008; El-Deek et al., 2010).

A considerable attention has been paid to use untraditional feedstuffs such as agro-industrial byproducts in formulating poultry diets to achieve a suitable efficiency of utilization and economic efficiency of production. Several attempts have been practiced to replace maize with date wastes in broiler diets (whole inedible dates, date pits, Mid-rib (MDP) and Pinne of date palm, PDP) but less consideration was given to the utilization of MDP. (El-Faham, 2005; El-Deek et al., 2010 and El Faham et al., 2013). Egypt, Kingdom of Saudi Arabia, Iran, Iraq, United Arab Emirates, Algeria and Pakistan are seven leading countries that produce more than $90 \%$ of the world's date supply. Also, dates are used for the production of molasses, alcohol, vinegar, yeast and several other products and the date by-products could be used in animal and poultry feeding (Daghir 2008; El-Deek et al., 2008).

Hussein et al. (1998) concluded that using whole dates or date pits, by $100 \mathrm{~g} / \mathrm{kg}$ in broiler starter rations had no adverse effect on growth and FCR of growing chicks. Also, El-Deek et al. (2010) indicated 


\section{El-Faham et al.}

possible inclusion of whole inedible date in broiler rations up to $150 \mathrm{~g} / \mathrm{kg}$ feed, during the period of 15 to 42 days of age without adverse effects on growth performance and meat quality. El-Faham (2005) concluded that, it is possible from the economic point of view to include MDP or PDP by $5 \%$ level in broiler diets (starter, grower and finisher). On the other hand, El-Faham et al. (2013) reported no harmful effects on performance of growing chicks upon feeding date palm waste 5, 10 and 15\% in starter, grower and finisher diets, respectively, supplemented with $5.0 \mathrm{~kg}$ Zado or $1.0 \mathrm{~kg}$ sodium sulphate/ ton.

Recently, reduced dietary protein and /or metabolically energy levels have been the subject of numerous investigators (Abd-Elsamee et al., 2001; Attia et al., 2001; El-Faham and Ibrahim, 2004). These authors concluded that body weight and feed conversion were significant improved with increasing crude protein level. However, chicks fed on low protein diets supplemented with essential amino acids (Han et al., 1992) or with Enramycin (Abd-Elsamee et al., 2001) or with phytase enzyme (Attia et al., 2001) could perform equivalently to those fed on higher protein diets. Thus, this study aims to investigate the effect of different levels of protein and Mid-rib of date palm (MDP) in broiler diets during starting and growing periods on growth performance, carcass characteristics and some physiological parameters.

\section{MATERIALS AND METHODS}

The present trial was conducted at poultry experimental unit, Agriculture Experiment and Research station at Shalakan, Faculty of Agriculture, Ain Shams University.

\section{Experimental diets and birds:}

Mid-rib of date palm waste (MDP) were collected from El-Wadi el-Gedid Governorate. MDP used in this study were sun dried and crushed to about $1 \mathrm{~mm} 3$ as a maximum size using a heavy-duty highrotation hammer mills. A representative sample of MDP was collected for proximate chemical analyses (Table 1), for assessment dry matter (DM), crude protein (CP), crude fiber (CF), ether extract (EE), nitrogen-free extract (NFE), crude ash (CA) and organic matter (OM), according to AOAC (1990). One

Table (1): Chemical composition of mid-rib of date palm (MDP) and yellow corn.

\begin{tabular}{lcc}
\hline Assay $\%$ & Mid-rib of date palm * & Yellow corn ** \\
\hline Dry matter & 88.10 & 88.00 \\
Crude protein & 2.69 & 7.70 \\
Crude fiber & 34.02 & 2.30 \\
Ether extract & 2.98 & 3.80 \\
Nitrogen-free extract & 41.70 & 72.22 \\
Crude ash & 6.71 & 14.00 \\
Organic matter & 93.29 & 86.00 \\
ME (Kcal/ kg) $* * *$ & 695 & 3350 \\
\hline
\end{tabular}

* Chemical composition parameters were determined in feed analysis lab, poultry production department. Faculty of Agriculture, Ain Shams University. ** Yellow corn parameters were calculated according to CLFF Bulletin (2001). *** According to El-Faham (2005).

hundred sixty unsexed one-day-old Hubbard broiler chicks were randomly distributed into 4 treatments with 5 replicates of 8 chicks. The four experimental treatments were as follows:

Control

Treatment 1 (T1)

Treatment 2 (T2)

Treatment 3 (T3)
Required protein + Required energy

Low protein $(-2 \%)+$ Required energy

Required protein + Low energy (5\% MDP)

Required protein + Low energy (10\% MDP)

As shown in Table (2), the experimental diets were based on corn-soy diets and control diets formulated to meet the nutrient requirements of broiler chicks according to NRC (1994).

\section{Growth performance:}

Individual live body weight and group feed consumption were recorded at the end of 3 and 5 weeks of age, while live body weight gain and feed conversion (feed/gain) were calculated every 3 or 2 weeks in relation to the feeding regimes. 
Egyptian J. Nutrition and Feeds (2017)

Table (2): Composition and chemical analysis of the starter and grower diets.

\begin{tabular}{lcccccccc}
\hline & \multicolumn{3}{c}{ Starter diets $(0-3$ weeks $)$} & \multicolumn{3}{c}{ Grower diets (4-5 weeks) } \\
\cline { 2 - 9 } Ingredient \% & Control & T1 & T2 & T3 & Control & T1 & T2 & T3 \\
\hline Yellow Corn & 46.72 & 54.30 & 41.72 & 36.72 & 54.75 & 60.28 & 49.75 & 44.75 \\
Mid-rib (MDP) & - & - & 5.00 & 10.00 & - & - & 5.00 & 10.00 \\
Soybean Meal (44\%) & 36.20 & 30.15 & 36.20 & 36.20 & 30.15 & 25.29 & 30.15 & 30.15 \\
Full-fat Soybeans & 9.00 & 9.00 & 9.00 & 9.00 & 9.00 & 9.00 & 9.00 & 9.00 \\
Soy Oil + Sunflower Oil & 3.65 & 2.00 & 3.65 & 3.65 & 2.00 & 1.50 & 2.00 & 2.00 \\
Mono calcium phosphate & 1.58 & 1.68 & 1.58 & 1.58 & 1.35 & 1.40 & 1.35 & 1.35 \\
Limestone & 1.60 & 1.62 & 1.60 & 1.60 & 1.50 & 1.48 & 1.59 & 1.50 \\
Salt (NaCl) & 0.40 & 0.40 & 0.40 & 0.40 & 0.40 & 0.40 & 0.40 & 0.40 \\
DL-methionine & 0.34 & 0.20 & 0.34 & 0.34 & 0.20 & 0.12 & 0.20 & 0.20 \\
L-lysine HCl & 0.08 & 0.22 & 0.08 & 0.08 & 0.22 & 0.10 & 0.22 & 0.22 \\
Vitamin \& Mineral Mix* & 0.30 & 0.30 & 0.30 & 0.30 & 0.30 & 0.30 & 0.30 & 0.30 \\
Choline chloride 50\% & 0.13 & 0.13 & 0.13 & 0.13 & 0.13 & 0.13 & 0.13 & 0.13 \\
Total & 100.0 & 100.0 & 100.0 & 100.0 & 100.0 & 100.0 & 100.0 & 100.0 \\
Chemical Analysis (Calculated) & $* *$ & & & & & & & 20.51 \\
Crude protein \% & 22.93 & 20.93 & 22.56 & 22.43 & 20.93 & 19.06 & 20.68 & 20.13 \\
Crude fiber \% & 4.25 & 3.99 & 5.84 & 7.42 & 3.99 & 3.77 & 5.58 & 7.17 \\
ME (Kcal/kg) & 3030 & 3029 & 2897 & 2765 & 3029 & 3055 & 2896 & 2764 \\
Calorie/Protein ratio & 132 & 145 & 128 & 123 & 145 & 160 & 140 & 135 \\
Calcium \% & 1.00 & 1.00 & 1.00 & 1.00 & 0.90 & 0.90 & 0.90 & 0.90 \\
Available phosphorus\% & 0.51 & 0.52 & 0.51 & 0.51 & 0.45 & 0.45 & 0.45 & 0.45 \\
Lysine \% & 1.48 & 1.40 & 1.48 & 1.48 & 1.40 & 1.21 & 1.40 & 1.40 \\
Methionine \% & 0.72 & 0.55 & 0.72 & 0.72 & 0.55 & 0.45 & 0.55 & 0.55 \\
Methionine + cysteine \% & 1.09 & 0.87 & 1.09 & 1.09 & 0.87 & 0.77 & 0.87 & 0.87 \\
\hline
\end{tabular}

* Each $3 \mathrm{~kg}$ of premix contains: 15000000 I.U VIT. A, 50 g. VIT. E, $3000 \mathrm{mg}$. VIT. K3, $3000 \mathrm{mg}$. VIT. B1, $8000 \mathrm{mg}$. VIT. B2, $4000 \mathrm{mg}$. VIT. B6, $20 \mathrm{mg}$. VIT. B12, $15000 \mathrm{mg}$. Pantothenic acid, $60000 \mathrm{mg}$. Niacin, $1500 \mathrm{mg}$. Folic acid, $200 \mathrm{mg}$. Biotin, $200000 \mathrm{mg}$, vit. C, $700 \mathrm{gm}$. Choline chloride, $80 \mathrm{gm} . \mathrm{Mn}, 80 \mathrm{gm}$. Zn, $60 \mathrm{gm}$. Iron, $10 \mathrm{gm} . \mathrm{Cu}, 1 \mathrm{gm}$. Iodine, and $0.2 \mathrm{gm}$. Selenium, where CaCo3 was taken as a carrier up to $3 \mathrm{~kg}$, the inclusion rate was $3 \mathrm{~kg}$ premix $/$ Ton feed. ** The figures for ingredients were calculated according to CLFF Bulletin (2001).

\section{Carcass characteristics:}

At the end of the experiment (5 weeks), 3 birds from each treatment were randomly selected and sacrificed for carcass measurements. Carcass, heart, liver, gizzard and abdominal fat were weighed and relative weights to live body weight were calculated. Carcass parts \% were evaluated using (breast, thigh, drumstick and wing) weights and percentages were calculated in relation to carcass weight.

\section{Bone traits:}

Tibia bones were removed, cleaned of all soft tissues and weighed. Tibia length and width were determined using a digital micrometer according to the methods described by Samejima (1990). The Seedor index (SI) was determined according to Seedor et al. (1991).

\section{Blood parameters:}

Blood samples were collected from slaughtered birds and plasma were separated by centrifugation at 3000 (rpm) for 15 minutes. Clear plasma samples were separated into Eppendorf tubes and kept in deep freezing at $\left(-20^{\circ}\right) \mathrm{c}$ until bio-chemical analysis. All biochemical parameters of plasma were colorimetrically determined using commercial diagnosing kits produced by (Bio-Diagnostics Company, Egypt).

\section{Statistical Analysis:}

Data were statistically analyzed by analysis of variance (ANOVA) one-way using the General Linear Model (GLM) procedure of SAS (2004). Mean were compared using Duncan's Multiple Range Test (Duncan, 1955) where the level of significance set at minimum $(\mathrm{P} \leq 0.05)$. 


\section{RESULTS AND DISCUSSION}

\section{Chemical composition and nutritive values of MDP against yellow corn}

Results of proximate analysis (on dry weight basis) of Mid-rib of date palm (MDP) used in this research in comparison with yellow corn was summarized in Table (1). The experimental data showed that yellow corn contains high amounts of crude protein, ether extract, crude ash and nitrogen free extract as compared to MDP. On the other hand, MDP contained highest value in crude fiber (34.02\%), while yellow corn was lower (2.30). This high fiber percentage may limit the diet inclusion level of most of date wastes, especially date pits, MDP and PDP in poultry diets (Jumah et al., 1973; Yeong et al., 1981; Sawaya et al., 1984; El-Boushy and Van Der Poel, 1994; El-Faham, 2005). The calculated metabolizable energy (ME) was $695 \mathrm{kcal} / \mathrm{kg}$ in MDP on the basis of its chemical composition according to Carpenter and Clegg (1956). This was much lower than yellow corn (3350 kcal/ kg) according to NRC (1994).

\section{Live body weight and body weight gain}

The live body weight and body weight gain of broiler as affected by dietary treatments are illustrated in Table (3). It is worth to note that the chicks fed low protein diets (T1) during studied periods (0-3 and 0-5 weeks) reflected the lowest insignificant results in both live body weight and body weight gain compared with control group. However, during the starting period (0-3 weeks), chicks decreased by $8.7 \%$ (808.67vs. $885.33 \mathrm{~g}$ ), while in whole experiment period (0-5 weeks) were 3.7\% (1914.27 vs. 1989.47). The explanation of that could be related to the fact that control diets were formulated to meet the optimum nutrient requirements for broiler chicks based on the recommendations of NRC (1994). On the other hand, chicks fed 5\% MDP gave slightly higher live body weight gain during starting period (0-3 wks) being ( 814.50 vs. 757.00$)$ or whole experimental period being (1801.87 vs. 1775.57), with significant differences. There were significant $(\mathrm{P}<0.05)$ differences among treatments in body weight compared with control group. In the same order, chicks fed 10\% MDP showed the highest reduction in body weight gain being 9.6 and $10.8 \%$ in starting and whole experimental periods respectively compared with the control group. A possible explanation for this reduction may be due to its highest fiber content over $7 \%$ in starter or grower diets which reduce digestibility and availability of nutrient (Table 2). The same trend was observed by some investigators (Sawaya et al., 1984; El-Boushy and Van Der Poel 1994;

Table (3): Effect of different dietary treatments on growth performance of broiler chicks

\begin{tabular}{clcccccc}
\hline \multirow{2}{*}{ Item } & & \multicolumn{4}{c}{ Dietary treatments } & \multirow{2}{*}{ SE } & \multirow{2}{*}{ Sig. } \\
\cline { 3 - 6 } & & Control & T1 & T2 & T3 & & \\
\hline \multirow{2}{*}{ LBW (g) } & Initial body weight & 47.83 & 46.83 & 47.50 & 47.00 & 1.53 & NS \\
& 3 weeks body weight & $885.33^{\mathrm{a}}$ & $808.67^{\mathrm{ab}}$ & $862.00^{\mathrm{ab}}$ & $804.00^{\mathrm{b}}$ & 22.54 & $*$ \\
& 5 weeks body weight & $2037.30^{\mathrm{a}}$ & $1961.10^{\mathrm{ab}}$ & $1849.37^{\mathrm{bc}}$ & $1822.57^{\mathrm{c}}$ & 27.81 & $*$ \\
Starter & Body weight gain (g) & $837.50 \mathrm{a}$ & $761.83^{\mathrm{ab}}$ & $814.50^{\mathrm{ab}}$ & $757.00^{\mathrm{b}}$ & 22.48 & $*$ \\
$(0-3)$ weeks & Feed intake (g) & 1100.00 & 1184.00 & 1182.00 & 1192 & 30.79 & $\mathrm{NS}$ \\
& FCR (g feed/g gain) & $1.31^{\mathrm{c}}$ & $1.55^{\mathrm{a}}$ & $1.45^{\mathrm{b}}$ & $1.57^{\mathrm{a}}$ & 0.016 & $*$ \\
Grower & Body weight gain (g) & $1151.97^{\mathrm{a}}$ & $1152.43^{\mathrm{a}}$ & $987.37^{\mathrm{b}}$ & $1018.57^{\mathrm{ab}}$ & 30.68 & $*$ \\
$(4-5)$ weeks & Feed intake (g) & $2255^{\mathrm{ab}}$ & $2427^{\mathrm{a}}$ & $2154^{\mathrm{b}}$ & $2246^{\mathrm{ab}}$ & 52.30 & $*$ \\
& FCR (g feed/g gain) & 1.96 & 2.12 & 2.19 & 2.20 & 0.09 & $\mathrm{NS}$ \\
Overall & Body weight gain (g) & $1989.47^{\mathrm{a}}$ & $1914.27^{\mathrm{ab}}$ & $1801.87^{\mathrm{bc}}$ & $1775.57^{\mathrm{c}}$ & 27.54 & $*$ \\
$(0-5)$ weeks & Feed intake (g) & 3355 & 3611 & 3336 & 3438 & 80.16 & $\mathrm{NS}$ \\
& FCR (g feed/g gain) & $1.68^{\mathrm{b}}$ & $1.89^{\mathrm{a}}$ & $1.85^{\mathrm{ab}}$ & $1.94^{\mathrm{a}}$ & 0.05 & $*$ \\
\hline
\end{tabular}

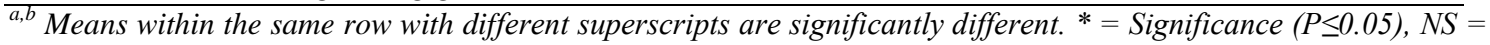
Non significant FCR: Feed Conversion Ratio.

El-Faham, 2005). Also, Onwudikee, (1986a, 1986b), reported that dates contain lower levels of essential amino acids, such as lysine, methionine leucine and isoleucine and its content which are not enough to meet optimum requirements for chick growth. The responses of chicks fed different experimental diets showed that chicks fed low protein diets (T1; -2\% crude protein) presented higher body weight than those fed the two different levels of MDP (low energy diets; 5 and 10\% MDP), T2 or T3. The corresponding 
figures were $1961.10,1849.37$ and $1822.57 \mathrm{~g}$ respectively and the differences failed to be significant compared with those fed control diet $(2037.30 \mathrm{~g})$. These findings were in contrast with thos obtained by El-Faham et al. (2013) who recommended to use (MDP) at inclusion rate of 5, 10 and 15\% in starter, grower and finisher chick diets, respectively without any adverse effects on productive performance comparable to the control of (Sasso x Gemmizah, Egyptian local strain). In the same order, Vandepopuliere et al. (1995) stated that feeding broiler chicks on diets containing higher levels of whole dates $(43 \%)$ and date pits $(27 \%)$ presented better productive performance. They found it difficult to determine if the positive growth response of chicks was due to higher fat levels or using date pits in diets.

\section{Feed consumption and feed conversion ratio}

Data in Table (3) indicated that feed intake per bird, (g) was insignificantly increased by feeding low protein diets (T1) compared with those fed control diets. The increase in feed intake during starting, growing and whole experimental period being $7.6 \%$. This might be due to the fact that $\mathrm{T} 1$ diets contained lower protein compared to the control diets. In the same order, genetically, broiler chicks require more dietary protein to maximize growth during short rearing periods. Feed conversion showed the same trend since chicks fed control diet were more efficient in converting their food into gain compared with those fed (T1) diets and differences were significant $(\mathrm{P} \leq 0.05)$. It was obvious from (Table 3$)$ that the effect of MDP (T2, T3) on feed intake and feed conversion during different experimental periods led chicks to consume more feed than control especially in starter period (0-3 weeks) without significant differences between treatments. In the same order, the figures of feed conversion ratio (FCR) presented significant differences between chicks fed diets containing MDP (T2, T3) compared with those fed control diets. The best FCR was detected for chicks fed control diets (1.68). On the other hand, the worst FCR were found in birds fed higher levels of $10 \%$ MDP (1.94), which could be due to lower body weight gain and higher feed intake (Table 3) as a result of higher dietary fiber content. Onwudikee (1986b) showed that high level of fiber in poultry diets showed negative response on the availability of amino acids and increase the passage of ingesta in the intestines, resulting in an increase in feed intake, a lower body weight and a poor feed conversion (Jumah et al., 1973).

\section{Carcass characteristics}

Table (4) shows the effect of different dietary treatments on carcass characteristics and carcass parts of broiler chicks slaughtered at the end of the experiment ( 5 weeks of age). Experimental treatments (T13 ) had no significant effect on studied parameters compared with control, except liver and giblets

Table (4): Effect of different dietary treatments on carcass characteristics, at 5 weeks.

\begin{tabular}{|c|c|c|c|c|c|c|}
\hline \multirow{2}{*}{ Item } & \multicolumn{4}{|c|}{ Dietary treatments } & \multirow{2}{*}{ SE } & \multirow{2}{*}{ Sig. } \\
\hline & Control & $\mathrm{T}_{1}$ & $\mathrm{~T}_{2}$ & $\mathrm{~T}_{3}$ & & \\
\hline Live body weight (g) & 1996.67 & 1755.00 & 1776.67 & 1760 & 160 & NS \\
\hline Carcass weight (g) & 1460.00 & 1260.00 & 1278.33 & 1241.67 & 50 & NS \\
\hline Carcass $\%$ & 73.12 & 71.80 & 71.95 & 70.55 & 1.29 & NS \\
\hline Liver $\%$ & $1.44^{\mathrm{b}}$ & $2.57^{\mathrm{a}}$ & $1.88^{\mathrm{ab}}$ & $2.18^{\mathrm{ab}}$ & 0.24 & $*$ \\
\hline Gizzard \% & 1.18 & 1.24 & 1.31 & 1.33 & 0.10 & NS \\
\hline Heart $\%$ & 0.33 & 0.49 & 0.38 & 0.47 & 0.10 & NS \\
\hline Giblets $\%$ & $2.94^{\mathrm{b}}$ & $4.29^{\mathrm{a}}$ & $3.56^{\mathrm{ab}}$ & $3.98^{\mathrm{a}}$ & 0.26 & $*$ \\
\hline Total edible parts $\%$ & 76.09 & 76.08 & 75.52 & 74.53 & 0.85 & NS \\
\hline Abdominal fat $\%$ & 1.69 & 1.68 & 1.87 & 1.61 & 0.28 & NS \\
\hline Wing & 9.70 & 9.84 & 12.61 & 11.54 & 1.11 & NS \\
\hline$\underbrace{\infty}_{\infty}$ Drumstick & 13.73 & 14.05 & 15.01 & 15.46 & 1.73 & NS \\
\hline : & $37.88^{\mathrm{a}}$ & $36.38^{\mathrm{a}}$ & $23.96^{\mathrm{b}}$ & $28.03^{\mathrm{ab}}$ & 2.01 & $*$ \\
\hline Breast & $38.69^{b}$ & $39.74^{\mathrm{b}}$ & $48.43^{\mathrm{a}}$ & $45.36^{\mathrm{a}}$ & 2.50 & $*$ \\
\hline
\end{tabular}

percentages. The corresponding values for carcass percentages ranged between 70.55 and $73.12 \%$, while total edible part percentages ranged between 74.53 and $76.09 \%$ and broiler chicks fed control diets gave the highest figure while, chicks fed $10 \%$ MDP had the lowest figures and differences among treatments 


\section{El-Faham et al.}

were insignificant. On the contrary, liver and giblets percentage figures showed significant difference between treatments, in which control group reflected the lowest figures compared with other treatments (T1-3) and the corresponding figures being 1.44 and 2.94\%, while chicks fed low protein diets (T1) gave the highest figures, being 2.57 and $4.29 \%$ respectively and in most cases differences between treatments were significant $(\mathrm{P} \leq 0.05)$.

\section{Carcass parts percentages}

The results in Table (3) shows the relationship between dietary treatments and carcass parts of broiler chicks. No significant differences in wing and drumstick percentages were obtained due to experimental treatments, but there was significant increase in breast percentages by feeding MDP diets (T2, T3) compared with those fed control or T1 diets, the corresponding figures were (48.43 and 45.36 vs. 38.69 and 39.74\%), respectively. On the contrary, chicks fed MDP diets (T2, T3) showed the lowest thigh percentage figures being 23.96 and $28.03 \%$, respectively while, chicks fed control or T1 diets had the highest figures being 37.88 and $36.38 \%$, respectively. The differences among treatments were significant $(\mathrm{P} \leq 0.05)$. Similar observations have been reported by El-Faham et al. (2013), Al-Homidan (2003) and Hussein et al. (1998). They concluded that adding date waste to broiler diets had no effect on carcass yield. In addition, these findings are in contrast with the results obtained by El-Faham (2005), who reported that added MDP in broiler chicks diets, significantly decreased dressing and breast $\%$ but increased drumstick \%.

\section{Bone measurements}

Results in Table (5) show the relationship between different dietary treatments and some tibia measurements. Wet tibia weight ranged between 10.59 and 9.5 (g.) and chicks fed diets containing MDP (T2, T3) gave the lowest figures while, chicks fed control diets or T1 diets gave the highest figures and differences among treatments were insignificant. In the same order, tibia length $(\mathrm{cm})$, tibia width $(\mathrm{cm})$ and tibia Seeder index figures, presented similar trend, in which control group reflected higher figures compared with other treatments and the corresponding figures being 8.53, 0.63 and $0.61(\mathrm{~cm})$, respectively. Differences among treatments were not significant. Similar observations have been reported by El-Faham et al. (2013) who reported that, no adverse effects of MDP inclusion at different levels with or without different feed additives on tibia measurements.

Table (5): Effect of different dietary treatments on some bone measurements

\begin{tabular}{|c|c|c|c|c|c|c|}
\hline \multirow{2}{*}{ Item } & \multicolumn{4}{|c|}{ Dietary treatments } & \multirow{2}{*}{ SE } & \multirow{2}{*}{ Sig. } \\
\hline & Control & $\mathrm{T} 1$ & $\mathrm{~T} 2$ & T3 & & \\
\hline Wet tibia weight (g) & 10.61 & 10.59 & 10.01 & 9.5 & 0.54 & NS \\
\hline Percentage of body weight & 0.53 & 0.61 & 0.56 & 0.54 & 0.14 & NS \\
\hline Tibia length (cm) & 8.53 & 8.40 & 8.23 & 8.17 & 0.13 & NS \\
\hline Tibia width (cm) & 0.63 & 0.62 & 0.62 & 0.57 & 0.02 & NS \\
\hline Tibia seeder Index & 0.61 & 0.60 & 0.59 & 0.56 & 0.02 & NS \\
\hline
\end{tabular}

\section{Blood plasma parameters}

Table (6) showed the effect of different treatments on some plasma parameters. It is clear that, although, total protein, Albumin, globulin and $\mathrm{A} / \mathrm{G}$ ratio have not significant different between treatments, total protein and globulin values for chicks that fed 5\% MDP (T2) diets have the lowest values being 5.70 and $1.79(\mathrm{~g} / \mathrm{dl})$ respectively, while (T1) diets recorded higher levels, being 7.75 and $3.80(\mathrm{~g} / \mathrm{dl})$ respectively. Which means, treatment $(\mathrm{T} 1)$ had improved immunity of birds compared to other groups. On the other hand, T2 diets recorded the highest value for $\mathrm{A} / \mathrm{G}$ ratio (2.18) compared with other treatments without any significant differences between treatments. Regarding kidney functions as uric acid concentration, different treatments were not significantly affected on kidney function and the corresponding values for uric acid ranged between 3.55 and $4.16(\mathrm{mg} / \mathrm{dl})$ and lower value for birds fed low protein diet (T1), and these results were logic as consuming lower protein presents inferior blood plasma uric acid concentration. According to lipid metabolism, chick fed (T1) diets showed the lowest triglycerides figure $(60.66 \mathrm{mg} / \mathrm{dl})$ and the highest total lipids and cholesterol being (497.03 and 210.23 
$\mathrm{mg} / \mathrm{dl}$ ) respectively, compared with other treatments. Generally, inclusion of MDP in diets (5 - 10\%), had decreased lipid metabolism, as presented in Table (6), especially for cholesterol values when comparing control group with (T1) group [173.27 and 179.33 vs. 183.50 and 210.23] for control and T1, respectively. Besides, differences between treatments were insignificant. Concerning liver function, aspartate transaminase (AST) was significantly different between treatments, while alanine transaminase (ALT) was not affected. In addition birds fed (T1) diets gave the highest figures (41.00 and 18.04 $\mathrm{RFU} / \mathrm{ml}$ ) for AST and ALT respectively compared to other treatments. These results are fairly logic as AST value represents liver function and reflect any stress on bird's body which in turn affect liver enzymes (AST and ALT). Also, dietary protein level was effective in altering blood plasma AST levels. In the present trial, decreasing dietary protein level had decreased AST concentration as presented with (T1) group. On the other hand, obtained results disagreed with Dairo et al. (2010) and Saleh (2016) they reported that, plasma AST and ALT were not affected by decreasing dietary protein by $1 \%$.

Table (6): Effect of different dietary treatments on some plasma parameters

\begin{tabular}{lcccccc}
\hline \multirow{2}{*}{ Item } & \multicolumn{4}{c}{ Dietary treatments } & \multirow{2}{*}{ SE } & \multirow{2}{*}{ Sig. } \\
\cline { 2 - 5 } & Control & T1 & T2 & T3 & & \\
\hline Total protein (g/dl) & 6.72 & 7.75 & 5.70 & 6.69 & 0.54 & NS \\
Albumin (g/dl) & 3.99 & 3.94 & 3.91 & 3.77 & 0.13 & NS \\
Globulin (g/dl) & 2.73 & 3.80 & 1.79 & 2.92 & 0.51 & NS \\
A/G ratio & 1.46 & 1.04 & 2.18 & 1.29 & 0.40 & NS \\
Uric acid (mg/dl) & 3.87 & 3.55 & 4.16 & 4.10 & 0.95 & NS \\
Total lipids (mg/dl) & 428.23 & 497.03 & 411.63 & 409.25 & 95.80 & NS \\
Triglycerides (mg/dl) & 83.33 & 60.66 & 61.33 & 64.67 & 6.00 & NS \\
Cholesterol (mg/dl) & 183.50 & 210.23 & 173.27 & 179.33 & 21.60 & NS \\
AST (RFU/ml) & $27.50^{\mathrm{ab}}$ & $41.00^{\mathrm{a}}$ & $21.17^{\mathrm{b}}$ & $30.85^{\mathrm{ab}}$ & 4.75 & $*$ \\
ALT (RFU/ml) & 15.11 & 18.04 & 17.97 & 13.66 & 1.34 & NS \\
\hline
\end{tabular}

$a, b$ Means within the same row with different superscripts are significantly different. $*=$ Significance $(P \leq 0.05) . N S=$ Non significant

\section{CONCLUSION}

After reviewing results of the present study, it is clear that feeding broiler chickens on balanced diets is more successful in regard to growth performance, feed conversion ratio and carcass characteristics.

\section{REFERENCES}

Abd-Elsamee, M.O.; O.M. El-Husseiny and A.M. Ali (2001). Effects of dietary crude protein and Enramycin supplementation on broiler performance. Egypt. Poult. Sci., 11: 507-520.

Al-Homidan, A.H. (2003). Date waste (whole dates and date pits) as ingredients in broiler diets. Egypt. Poult. Sci., 23(1): 15-35.

AOAC (1990). Association of Official Analytical Chemists. Methods of analysis, 15th edition Arlington, USA.

Attia, Y.A.; S. Abd El-Rahman and E.M.A. Qota (2001). Effects of microbial phytase without or with cell-wall splitting enzymes on the performance of broilers fed marginal levels of dietary protein and metabolizable energy. Egypt. Poult. Sci., 11: 520-548.

Carpenter, K.J. and K.M. Clegg (1956). The metabolizable energy of Poultry feeding-stuffs in relation to their chemical composition. J. Sci. Food Agric., 7: 45-51.

Daghir, N. (2008). Poultry production in hot climates. 2nd Ed.. CABI Publishing Wallingford, UK.

Dairo, F.A.S.; A.O.K. Adesehinrva; T.A. Oluwasola and J.A. Oluyemi (2010). High and low dietary energy and protein levels for broiler chickens. African J. Agric. Res., 5: 2030-2038.

Duncan, D.B. (1955). Multiple range and multiple F tests. Biometrics, 11: 1-42. 


\section{El-Faham et al.}

El-Faham, A.I., S.A. Ibrahim; N.G.M. Ali; M.E. Mohamed and M.K. Ekramy (2013). Effect of date palm waste and some feed additives on growing chick performance. Egypt. Poult. Sci., 16(2): 381-390.

El-Faham, A.I. and M.T. Ibrahim (2004). Effect of enzyme supplementation on performance, meat quality and economic evaluation of broiler chicks fed low protein diets. Annals of Agric. Sci. Moshtohor, 42(3): 1009-1026.

El-Boushy, A.R.Y. and A.F.B. Van Der Poel (1994). Poultry feed from waste: processing and use. Champan \& Hall, UK. pp: 276-286.

El-Deek, A.A.; M. Al-Harthi and H.M. Yakout (2008). Use of enzymes to supplement diets containing date waste meal for Lohman layers. Int. J. Poult. Sci., 7: 397-407.

El-Deek, A.A; Y.A. Attia and M.A. Al-Harthi (2010). Whole inedible date in the grower-finisher broiler diets and the impact on productive performance, nutrient digestibility and meat quality. Animal, 4(10): $1647-1652$.

El-Faham, A.I. (2005). The effect of using date palm waste (mid rib and pinne of date palm) as ingredients in broiler diets. J. Agric. Sci. Mansoura Univ., 30: 5103-5114.

Farrell, D. (2005). Matching poultry production with available feed resources: issues and constraints. World's Poult. Sci. J., 61: 298-307.

CLFF (2001). Central lab for feed and food. Technical Bulletin No. (1). Feed composition tables for animal and poultry feedstuffs used in Egypt, Ministry of Agriculture, Egypt.

Han, Y.; H. Suzuki; C.M. Parsons and D.H. Baker (1992). Amino acids fortification of a low-protein corn and soybean meal diet for chicks. Poult. Sci., 71: 1168-1178.

Hussein, A.S; G.A. Alhadrami and Y.H. Khalil (1998). The use of dates and date pits in broiler starter and finisher diets. Biores. Technol., 66: 219-223.

Jumah, H.F.; I.I. Al-Azzawi and S.A. Al-Hashimi (1973). Some nutritional aspects of feeding ground date pits for broiler. Mesopotamia J. Agric., 8(2): 139-145.

Lumpkins, B. and A. Batal (2005). Bioavailability of lysine and phosphorus in distillers' dried grains with solubles. Poult. Sci., 84: 581-586.

NRC (1994). National Research Council. Nutrient Requirements of Poultry 9th Rev. Ed. Composition of poultry feedstuffs. National Academy Press, Washington, DC, USA. PP 61-75.

Onwudikee, O.C. (1986a). Palm Kernel meal as a feed for poultry: 1-compstion of palm kernel and availability of its amino acids to chicks. Anim. Feed Sci. and Technol., 16: 179-186.

Onwudikee, O.C. (1986b). Palm Kernel meal as a feed for poultry. 3-replacement of groundnut cake by palm Kernel meal in broiler diets. Anim. Feed Sci., and Technol., 16: 196-202.

Saleh, A.A., (2016). Effect of low-protein in iso-energetic diets on performance, carcass characteristics, digestibilities and plasma lipids of broiler chickens. Egypt. Poult. Sci. 36: 251-262.

Samejima, M. (1990). Principal component analysis of measurements in the skeleton of red jungle fowl and 12 breeds of domestic fowls. III. Ossa membri pelvini. Jap. Poult. Sci., 27: 142-161.

SAS (2004). JMP Statistics and graphics Guide, SAS Institute, Cary, NC. USA.

Sawaya, W.N; U.K. Khalil and W.J. Safi (1984). Chemical composition and nutritional quality of date seed. J. food Sci., 49: 617-619.

Seedor, J.G.; H.A. Quarruccio and D.D. Thompson (1991). The biophosphonate alendronate (MK-217) inhibits bone loss due to ovariectomy in rats. J. Bone Miner. Res., 6: 339-346.

Swiątkiewicz, S. and J. Koreleski (2008). The use of distillers dried grains with solubles (DDGS) in poultry nutrition. World's Poult. Sci. J., 64: 257-265.

Vandepopuliere, J.M.; Y. Al-Yousef and J. J. Lyons (1995). Dates and date pits as ingredients in broiler starting and Coturnix quail breeder diets. Poult. Sci., 74 (7): 1134-1142.

Yeong, S.W.; T.K. Mukherjee and R.I. Hutagalung (1981). The nutritive value of palm kernel cake as a feedstuff for poultry. Proceedings of National workshop on oil palm by-products utilization. Kuala Lumpur, Malaysia, p.p. 100-107. 


\title{
مخلفات نخيل البلح فى علائق البادى \&-النامى والتاثير على الأداء الإنتاجى والفسيولوجى لاجاج التسمين
}

\author{
أحمد إبراهيم سليمان الفحام1، نعمة الله جمال الاين حملم على1، رهام على حملم على ومروان عبدالعزيز محمود عبدالعزيز11
}

\author{
"قسم إنتاج الدواجن ـ كلية الزراعة - جامعة عين شمس - مصر. \\ 2قسم الإنتاج الحيوانى والداجنى ـ كلية النزراعة والموارد الطبيعية ـ جامعة أسوان ـ مصر.
}

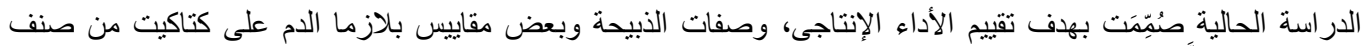

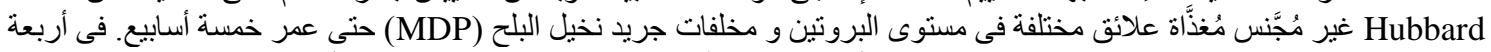

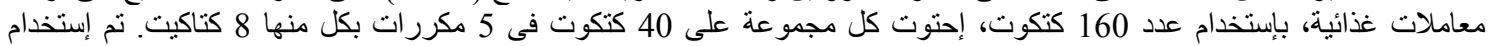

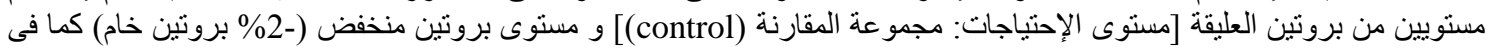

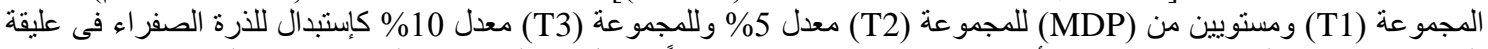

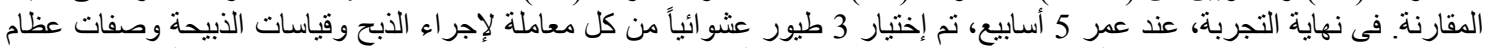

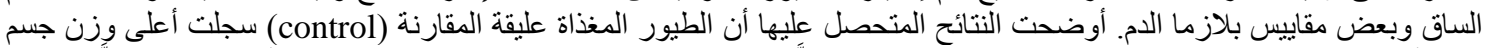

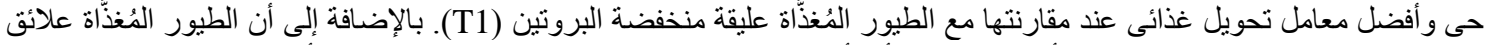

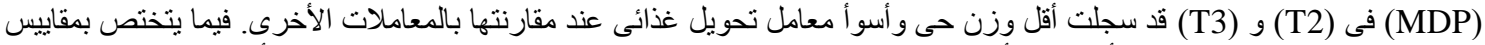

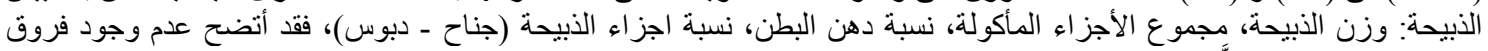

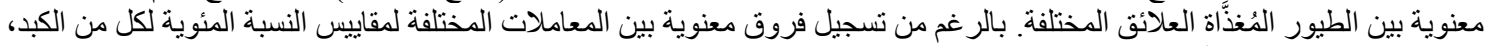

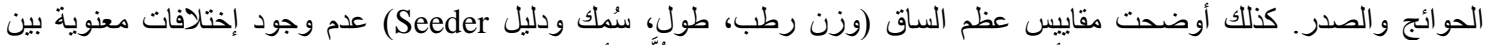

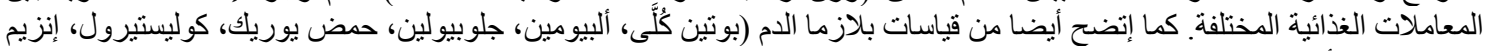

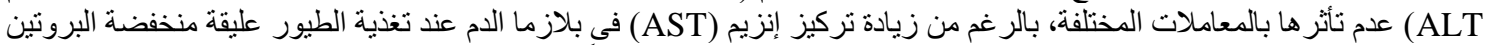

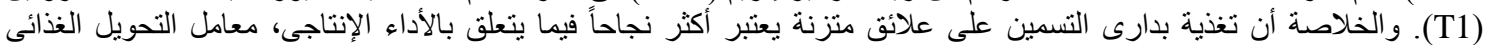

وصفات الذبيحة.
\end{abstract}

